\title{
Part 2: SYNTHESIS AND REACTIONS OF SOME NEW IMIDAZO[4,5- C]PYRAZOLE AND PYRAZOLO[3,4-D]PYRIMIDINE DERIVATIVES
}

\author{
MONA S. KADAH*, NAHED F. ABD EL-GHAFFAR, , AZZA M. RADWAN, \\ SARA N. ABD EL-AL AND ASMAA S. SALMAN \\ Al-Azhar University, Faculty of Science (Girls), Chemistry Department, Nasr City, \\ Cairo, AR Egypt. Corresponding author, E-mail: mkadh@yahoo.com
}

\begin{abstract}
Reactions of 3-methyl-1-phenyl-4,6-dihydroimidazo[4,5-c]pyrazole-5(1H)-thione with carbonyl compounds gave the arylidene derivatives 2 and 3, with recinoleic acid, phosphorus oxychloride/phosphorus pentachloride mixture and copper bronze gave the adduct 4 , the chloro derivative 5 and the dimer with desulfurization 7 . The behaviour of the chloroderivative towards hydrazine and primary amines have also been studied. On the other, reaction of 5-methyl-2-phenyl-2,4-dihydro-3H-pyrazol-3-one with aromatic aldehydes gave the arylidene derivatives $8 \mathrm{a}-\mathrm{d}$, which on reaction with thiourea gave the pyrazolopyrimidinethione derivatives 9 . The behaviour of compounds 9 towards copper bronze, sodium nitrite/acetic acid mixture, acrylonitrile and formaldehyde/ morpholine and its reaction with compound 1 in presence of copper bronze have also been taken into consideration.
\end{abstract}

Keywords: Pyrazoloimidazole, pyrazolopyrimidine, pyrazolone

A large number of pyrazoles are reported to exhibit CNS depressant ${ }^{1}$, antibacterial $^{2}$, antitumor ${ }^{3}$ and antagonists ${ }^{4}$ activities, while imidazoles exhibit antimicrobial $^{5}$, antitumor ${ }^{6}$ and antiproliferative ${ }^{7}$ activities. On the other hand, pyrazolopyrimidine derivatives exhibit anti-inflammatory, antitumor, antimycobacterial, antifungal and antiviral activities ${ }^{8-10}$.

In view of these reports and in continuation of our recent works ${ }^{11-13}$ we synthesized new imidazopyrazole and pyrazolopyrimidine derivatives.

\section{Experimental}

All melting points are uncorrected. IR spectra $(\mathrm{KBr})$ were recorded with a Pye Unicam SP3-200 spectrophotometer. ${ }^{1} \mathrm{H}-\mathrm{NMR}$ were measured with a Varian EM60 and Jeol-9 MHz instrument using TMS as internal standard and mass spectra were measured with a FINNI-Gas 3300 mass spectrometer.

The synthesis of various compounds are outlined in Schemes 1 and 2. 
Synthesis of 3-[2-(4-chlorophenyl) ethenyl] -1-phenyl -3a ,4-dihydroimidazo [4,5-c]pyrazole-5(1H)thione (2) and 4-methyl-5-(1-phenyl-5-thioxo-1,3a,4,5tetrahydroimidazo[4,5-c]pyrazol-3-yl]-4-penten-2-one (3)

A mixture of 1 (0.01 mol), p-chlorobenzaldehyde and/or acetyl-acetone (0.01 mol) was added in a course of 30 minutes to a well stirred solution of sodium ethoxide [prepared from sodium metal $(0.11 \mathrm{gm}$ in absolute ethanol (30 $\mathrm{ml})]$. Stirring was continued for further $3 \mathrm{~h}$, then the reaction mixture was left overnight. The excess alcohol was removed under reduced pressure and the residue was treated with water, acidified with dil. $\mathrm{HCl}$ and extracted with ether. The ethereal layer was washed with aqueous sodium carbonate, water and dried. The ether was removed under reduced pressure and the pale yellow solid obtained was crystallized from ethanol ( 2 m.p. $176^{\circ} \mathrm{C}, 3$ m.p. $198^{\circ} \mathrm{C}$ ). Analysis for $\mathrm{C}_{18} \mathrm{H}_{13} \mathrm{~N}_{4} \mathrm{SCl}$ (\%): Calcd. C 61.30, H 3.70, N 15.90, S 9.10, Cl 10.10); found C 61.00 , H 3.50, N 15.70, S 9.00 , Cl 10.00 ; for $\mathrm{C}_{16} \mathrm{H}_{16} \mathrm{~N}_{4} \mathrm{OS}$ (\%): Calcd. C 61.50, H 5.10, N 17.90, S 10.30; found C 61.30, H 5.00, N 17.70, S 10.00 .

\section{Synthesis of 11-hydroxy-9-[(3-methyl-1-phenyl-1,3a-dihydroimidazo [4,5- c]pyrazol-5-yl)sulfonyl]hexadecanoic acid (4)}

A mixture of 1 (0.01 mole) and recinoleic acid ( $0.01 \mathrm{~mol})$ in dry benzene (50 ml) containing few drops of piperidine was shaken vigorously, then left overnight. After removal of solvent under reduced pressure, the residue was triturated with light petrol (b.p. 40-60 ${ }^{\circ} \mathrm{C}$ ) and crystallized from benzene to give (4) (m.p. $70^{\circ} \mathrm{C}$ ). Analysis of $\mathrm{C}_{27} \mathrm{H}_{40} \mathrm{~N}_{4} \mathrm{O}_{3} \mathrm{~S}$ (\%): Calcd. C 64.80, H 8.00, N 11.20, S 6.40; found C 64.78, H 8.20, N 11.00, S 6.20.

\section{Synthesis of 5-chloro-3-methyl-1-phenyl-1,3a-dihydroimidazo[4,5-c] pyrazole}

(5)

A mixture of 1 (0.01 mol), phosphorus oxychloride (3 ml) and phosphorus pentachloride $(0.5 \mathrm{~g}$ ) was heated on a water bath for $2 \mathrm{~h}$., cooled then poured onto ice. The solid obtained was filtered off and crystallized from ethanol to give (5) (m.p. $232^{\circ} \mathrm{C}$ ). Analysis for $\mathrm{C}_{11} \mathrm{H}_{9} \mathrm{~N}_{4} \mathrm{Cl}$ (\%): Calcd. C 56.80, H 3.90, N 24.10, Cl 15.30; found C 56.60, H 3.70, N 24.00, S 15.00.

Synthesis of 5-substituted-3-methyl-1-phenyl-1,3a-dihydroimidazo [4,5-c] pyrazole (6a-d) 
Part 2: SYNTHESIS AND REACTIONS OF SOME NEW ....... 104

A mixture of 5 (0.01 mol), hydrazine hydrate and/or primary amine namely ethylamine, 2-aminopyridine, aniline $(0.01 \mathrm{~mol})$ in ethanol (30 ml) was refluxed for $3 \mathrm{~h}$. The solid obtained after concentration and cooling was crystallized from petroleum ether (b.p. $\left.60-80^{\circ} \mathrm{C}\right)\left(\mathbf{6 a}\right.$ m.p. $120^{\circ} \mathrm{C}$, $6 \mathrm{~b}$ m.p. $\left.135^{\circ} \mathrm{C}\right)$, propanol (6c m.p. $183^{\circ} \mathrm{C}$ ) or ethanol (6d m.p. $\left.160^{\circ} \mathrm{C}\right)$. Analysis for $\mathrm{C}_{11} \mathrm{H}_{12} \mathrm{~N}_{6}(\%)$ : Calcd C 57.90, H 5.30, N 36.80; found C 57.70, H 5.00, N 36.60; for $\mathrm{C}_{13} \mathrm{H}_{15} \mathrm{~N}_{5}$ (\%): Calcd. C 64.70, H 6.20, N 29.00; found C 64.50, H 6.00, N 29.20; for $\mathrm{C}_{16} \mathrm{H}_{14} \mathrm{~N}_{6}$ (\%): Calcd. C 66.20, H 4.80, N 29.00; found C 66.00, H 4.60, N 29.20; for $\mathrm{C}_{17} \mathrm{H}_{15} \mathrm{~N}_{5}$ (\%): Calcd. C 70.60, H 5.20, N 24.20; found C 70.40, H 5.00, N 24.00.

Synthesis of 5,5-bis [3-methyl-1-phenyl-4,6-dihydroimidazo[4,5-c] pyrazole (7) and bis 4-(2-hydroxy phenyl)-3-methyl-1-phenyl-1,5-dihydro-6H-pyrazolo[3,4d]pyrimidine-6-thione (10)

To a solution of $\mathbf{1}$ and/or $\mathbf{9}(0.01 \mathrm{~mol})$ in dry xylene (50 ml), copper bronze (3 g) was added and the reaction mixture was refluxed for $10 \mathrm{~h}$. The solid obtained after filtration the reaction mixture while hot, concentration and cooling was crystallized from benzene (7 m.p. $137^{\circ} \mathrm{C}$ ) or butanol (10 m.p. $272^{\circ} \mathrm{C}$ ). Analysis for $\mathrm{C}_{22} \mathrm{H}_{22} \mathrm{~N}_{8}(\%)$ : Calcd. C 66.30, H 5.50, N 28.10; found: C 66.60, H 5.30, N 28.00; for $\mathrm{C}_{36} \mathrm{H}_{26} \mathrm{~N}_{8} \mathrm{O}_{2}$ (\%): Calcd. C 71.80, H 4.30, N 18.60; found: C 71.60, H 4.00, N 18.40.

\section{Synthesis of the arylidene derivatives (8a-d)}

To a solution of 1-phenyl-3-methyl pyrazolone $(0.01 \mathrm{~mol})$ in sodium ethoxide solution [from sodium $0.02 \mathrm{~mol}$ in absolute ethanol $(20 \mathrm{ml})$ ], aromatic aldehydes namely salicylaldehyde, p-chlorobenzaldehyde, furfural and/or vanillin (0.01 mol) was added with stirring . Stirring was continued for further $3 \mathrm{~h}$, then left overnight. The excess alcohol was removed under reduced pressure and the residue was treated with water, then acidified with dil $\mathrm{HCl}$ and extracted with ether. The solid obtained after removing ether under reduced pressure was crystallized from ethanol (8a m.p. $187^{\circ} \mathrm{C}$, 8b m.p. $205^{\circ} \mathrm{C}$, 8c m.p. $197^{\circ} \mathrm{C}, 8 d$ m.p. $170^{\circ} \mathrm{C}$ ). Analysis for $\mathrm{C}_{17} \mathrm{H}_{14} \mathrm{~N}_{2} \mathrm{O}_{2}$ (\%): Calcd. C 73.40, H 5.00, N 10.10; found C 73.20, H 5.20, N 10.00; for $\mathrm{C}_{17} \mathrm{H}_{13} \mathrm{~N}_{2} \mathrm{OCl}$ (\%): Calcd. C 68.80, H 4.40, N 9.40, Cl 12.00; found C 68.60, H 4.80, N 9.20, Cl 12.20; for $\mathrm{C}_{15} \mathrm{H}_{12} \mathrm{~N}_{2} \mathrm{O}_{2}$ (\%): Calcd. C 71.40, H 4.80, N 11.10; found C 71.20, H 4.60, $\mathrm{N}$ 11.00; for $\mathrm{C}_{18} \mathrm{H}_{16} \mathrm{~N}_{2} \mathrm{O}_{3}$ (\%): Calcd. C 70.13, H 5.20, N 9.10; found C 70.10, H 5.19, N 9.09 .

Synthesis of 4-(arylidene-3-methyl-1-phenyl-1,5-dihydro-6H-pyrazolo [3,4d]pyrimidine-6-thione (9a-d) 
To a solution of $8 \mathrm{a}-\mathrm{d}, 10 \%$ sodium hydroxide $(10 \mathrm{ml})$, absolute ethanol $(30 \mathrm{ml})$, thiourea $(0.01 \mathrm{~mol})$ was added and the reaction mixture was refluxed for $6 \mathrm{~h}$. The solid obtained after removal of solvent was washed with water and crystallized from ethanol (9a m.p. $133^{\circ} \mathrm{C}, 9 \mathbf{b}$ m.p. $150^{\circ} \mathrm{C}$, 9c m.p. $140^{\circ} \mathrm{C}$, 9d m.p. $128^{\circ} \mathrm{C}$ ). Analysis for $\mathrm{C}_{18} \mathrm{H}_{14} \mathrm{~N}_{4} \mathrm{SO}$ (\%) Calcd: C 64.70, H 4.20, N 16.80, S 9.60; found: C 64.50, H 4.00, N 16.60, S 9.40; for $\mathrm{C}_{18} \mathrm{H}_{13} \mathrm{~N}_{4} \mathrm{SCl}$ (\%): Calcd C 61.28, H 3.69, N 15.89, S 9.10, Cl 10.7; found C 61.30, H 3.70, N 15.90, S 9.07, Cl 10.10; for $\mathrm{C}_{16} \mathrm{H}_{12} \mathrm{~N}_{4} \mathrm{SO}$ (\%): Calcd C 62.30, H 3.90, N 18.20, S 10.40; found C 62.50, H 3.70, N 18.00, S 10.20; for $\mathrm{C}_{19} \mathrm{H}_{16} \mathrm{~N}_{4} \mathrm{SO}_{2}$ (\%): Calcd C 62.60, H 4.40, N 15.40, S 8.80; found: C 62.40, H 4.20, N 15.20, S 8.60.

\section{Synthesis of 5-(6-\{[4-(3-hydroxy-4-methoxyphenyl)-3-methyl-1-phenyl-5,6-} dihydro-1H-pyrazolo[3,4-d]pyrimidine-6-yl]disulfonyl\}-3-methyl-1-phenyl-5,6dihydro-1H-pyrazolo[3,4-d]pyrimidin-4-yl)-2-methoxyphenol (11).

To a cooled well stirred suspension of $\mathbf{9}(0.01 \mathrm{~mol})$ in ethanol $(25 \mathrm{ml})$ was added portionwise a cooled aqueous solution of sodium nitrite $(0.04 \mathrm{~mol}$ in $25 \mathrm{ml}$ of water) and acetic acid $(2 \mathrm{ml})$. Stirring was continued for $3 \mathrm{~h}$ while keeping the temperature of the reaction mixture below $5^{\circ} \mathrm{C}$. The obtained product was filtered off, washed with water and crystallized from ethanol to give (11) (m.p. $230^{\circ} \mathrm{C}$ ). Analysis for $\mathrm{C}_{38} \mathrm{H}_{30} \mathrm{~N}_{8} \mathrm{O}_{4} \mathrm{~S}_{2}$ (\%): Calcd C 62.80, H 4.10, N 15.40, S 8.80; found C 62.60, H 4.00, N 15.20, S 8.60 .

\section{Synthesis of 3-\{[4-(2-hydroxyphenyl)-3-methyl-1-phenyl-5,6-dihydro-1H- pyrazolo[3,4-d]pyrimidin-6-yl]sulfonyl\}propanenitrile (12)}

To a solution of $9 \mathbf{a}(0.01 \mathrm{~mol})$ in pyridine $(20 \mathrm{ml})$, acrylonitrile $(0.02 \mathrm{~mol})$ was added and the reaction mixture was refluxed for $6 \mathrm{~h}$. After cooling, the reaction mixture was poured into cold $10 \% \mathrm{HCl}$. The separated product was filtered of, washed with water and crystallized from ethanol to give (12) (m.p. $122^{\circ} \mathrm{C}$ ). Analysis for $\mathrm{C}_{21} \mathrm{H}_{17} \mathrm{~N}_{5} \mathrm{OS}$ (\%): Calcd C 65.12, H 4.40, N 18.10, S 8.30; found C 65.10, H 4.42, N 18.12, S 8.32.

\section{Synthesis of 4-(2-furyl)-3-methyl-5-(4-morpholinyl methyl)-1-phenyl-1,5- dihydro-6H-pyrazolo[3,4-d]pyrimidine-6-thione (13).}

A mixture of $9 \mathbf{a}(0.01 \mathrm{~mol})$, formaldehyde $(40 \%, 0.7 \mathrm{ml})$, morpholine $(0.02 \mathrm{~mol})$ in a mixture of methanol-acetone (2:1) (50 ml), was refluxed for $18 \mathrm{~h}$. The residue obtained after removing of the solvent under reduced pressure, was triturated with 
Part 2: SYNTHESIS AND REACTIONS OF SOME NEW ....... 106 petroleum ether (b.p. $40-60^{\circ} \mathrm{C}$ ), then crystallized from ethanol to give 13 (m.p. $240^{\circ} \mathrm{C}$ ). Analysis for $\mathrm{C}_{21} \mathrm{H}_{21} \mathrm{~N}_{5} \mathrm{O}_{2} \mathrm{~S}$ (\%): Calcd. C 61.90, H 5.20, N 17.20, S 7.90; found C 61.70, H 5.00, N 17.00, S 7.70.

\section{Synthesis of 4-(2-furyl)-3-methyl-6-(3-methyl-1-phenyl)-1,3a,4,5- tetrahydroimidazo[4,5-c]pyrazolo-5-yl)-1-phenyl-1H-pyrazolo[3,4-d] pyrimidine (14).}

To a solution of $9 \mathrm{c}(0.01 \mathrm{~mol})$ and $1(0.01 \mathrm{~mol})$ in dry xylene $(50 \mathrm{ml})$, copper bronze ( $3 \mathrm{~g}$ ) was added and the reaction mixture was refluxed for $10 \mathrm{~h}$. The solid obtained after filtration the reaction mixture while hot, concentration and cooling was crystallized from butanol to give 14 (m.p. $260^{\circ} \mathrm{C}$ ). Analysis for $\mathrm{C}_{27} \mathrm{H}_{21} \mathrm{~N}_{8} \mathrm{O}$ (\%): Calcd. C 68.50, H 4.43, N 23.70; found C 68.50, H 4.40, N 23.72.

\section{Results and Discussion}

3-Methyl-1-phenyl-4,6-dihydroimidazo[4,5-c]pyrazole-5(1H)-thione (1) ${ }^{13}$ was used as key intermediate for the preparation of several imidazo[4,5-c]pyrazole derivatives.

Thus, reaction of $\mathbf{1}$ with carbonyl compounds namely p-chloro-benzaldehyde and/or acetyl acetone in the presence of sodium ethoxide (under Claisen reaction conditions) gave the condensed products 2 and 3, respectively. The structure of compound 2 was derived from correct analytical data and from the mass spectrum which showed the parent ion peak at $\mathrm{m} / \mathrm{z} 352$ (78.95\%) (calculated for the isotope ${ }^{35} \mathrm{Cl}$ ), while the structure of compound 3 was derived from correct analytical data and from the IR spectrum which showed bands at 1693, 1597, 1257, $3423 \mathrm{~cm}^{-1}$ for $\mathrm{C}=\mathrm{O}, \mathrm{C}=\mathrm{N}, \mathrm{C}=\mathrm{S}$ and $\mathrm{NH}$.

Compound 1 exists on a thione-thiol tautomerism. The existence of the thiol form was proved by the study of its behaviour towards unsaturated fatty acid namely recinoleic acid in dry benzene and in the presence of few drops of piperidine to give the adduct 4. Its IR spectrum was devoid of $\mathrm{C}=\mathrm{S}$ band and showed bands at 1729, 1616, $3324 \mathrm{~cm}^{-1}$ (broad) for $\mathrm{C}=\mathrm{O}$ (acid), $\mathrm{C}=\mathrm{N}, \mathrm{NH}$ and $\mathrm{OH}$. Its mass spectrum showed the parent ion peak at $\mathrm{m} / \mathrm{z} 500$ (63.36\%).

The reaction of the nucleophilic reagent phosphorus oxychloride with compound $\mathbf{1}$, also supports the presence of the thiol form. Thus, compound 1 reacts with $\mathrm{POCl}_{3} / \mathrm{PCl}_{5}$ to give the corresponding chloro derivative 5. Its IR spectrum showed the characteristic bands for $\mathrm{C}=\mathrm{N}$ and $\mathrm{C}-\mathrm{Cl}$ at 1600 and $492 \mathrm{~cm}^{-1}$, respectively. Its mass spectrum showed $\mathrm{M}-2]^{+}$at $\mathrm{m} / \mathrm{z} 230$ (61.9\%). 
7

The chloro compound $\mathbf{5}$ was used to prepare the hydrazine and substituted amino derivatives, by its reaction with hydrazine hydrate and primary amines namely ethylamine, 2-aminopyridine and/or aniline in boiling ethanol to give compounds $6 a-d$. The reaction proceeds through the nucleophilic attack at the carbon atom bearing the more electronegative chlorine atom, with one molecule of the $\mathrm{NH}_{2}$ component with the elimination of one molecule of $\mathrm{HCl}$. The IR spectrum of $6 \mathrm{c}$ showed bands for $\mathrm{C}=\mathrm{N}$ and $\mathrm{NH}$ at 1594 and $3423 \mathrm{~cm}^{-1}$.

Dimerization of compound $\mathbf{1}$ has also been taken into consideration. Thus, reaction of 1 with copper bronze in boiling xylene gave compound 7. Its IR spectrum showed bands at 1600,3338 (broad) $\mathrm{cm}^{-1}$ for $\mathrm{C}=\mathrm{N}$ and $\mathrm{NH}$.

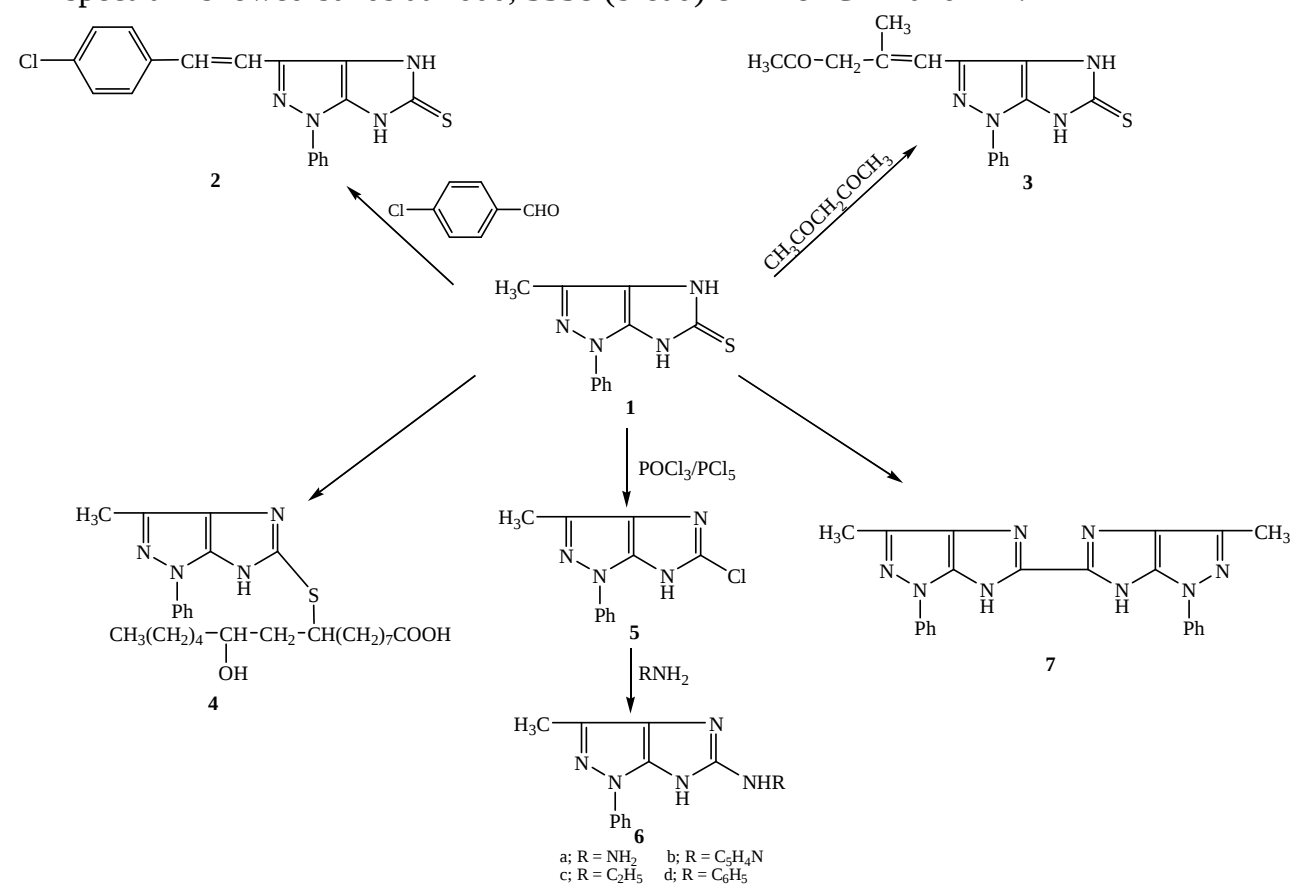

Scheme 1

Interestingly, reaction of 5-methyl-2-phenyl-2,4-dihydro-3H-pyrazol-3-one with aromatic aldehydes, namely salicylaldehyde, p-chloro benzaldehyde, furfural and/or vaniline in the presence of sodium ethoxide (Claisen conditions) affords the corresponding arylidene derivatives 8a-d. The IR spectra of 8a-c showed bands at 1701-1680, 1601-1598 $\mathrm{cm}^{-1}$ for $\mathrm{C}=\mathrm{O}$ and $\mathrm{C}=\mathrm{N}$, in addition a band at $3404 \mathrm{~cm}^{-1}$ for 
$\mathrm{OH}$ for compound 8a. The ${ }^{1} \mathrm{H}-\mathrm{NMR}$ (DMSO- $\mathrm{d}_{6}$ ) spectrum of $8 \mathrm{~b}$ exhibited signals at $\delta$ (ppm): 7.84-7.10 $(10 \mathrm{H}, \mathrm{m}, \mathrm{ArH}+=\mathrm{CH})$ and $2.20\left(3 \mathrm{H}, \mathrm{s}, \mathrm{CH}_{3}\right)$. The mass spectrum of $8 \mathrm{a}$ showed peak at $\mathrm{m} / \mathrm{z} 261 \mathrm{M}-\mathrm{OH}]^{+}(78.33 \%)$, while the mass spectrum of $8 \mathrm{~b}$ showed the parent ion peak at $\mathrm{m} / \mathrm{z} 296$ (44.40\%).

As stated above pyrimidine derivatives displayed a wide spectrum of pharmacological activities. In the present work, reaction of compounds 8a-d with thiourea gave the pyrazolopyrimidine derivatives 9a-d, which is in accordance with previous result ${ }^{14}$. The IR spectrum of 9c showed bands at $1620,1227,3417 \mathrm{~cm}^{-1}$ for $\mathrm{C}=\mathrm{N}, \mathrm{C}=\mathrm{S}$ and $\mathrm{NH}$.

Compound 9 was used for the preparation of several new pyrazolo-pyrimidine derivatives. Thus, treatment of 9a with copper bronze in boiling xylene gave the biscompound 10, the reaction is accompanied by desulfurization with dimerization of the thione 9a. The structure of compound 10 was derived from correct analytical data, from its IR spectrum which showed bands at $1594,3122 \mathrm{~cm}^{-1}$ for $\mathrm{C}=\mathrm{N}$ and $\mathrm{OH}$. Its ${ }^{1} \mathrm{H}-\mathrm{NMR}$ (DMSO-d ${ }_{6}$ ) spectrum exhibited signals at $\delta(\mathrm{ppm})$ 7.82-7.17 $(18 \mathrm{H}, \mathrm{m}$, Ar-H), 2.14 (6H, s, $2 \times \mathrm{CH}_{3}$ ) and 11.52 (2H, s, 2 x OH).

Interestingly, dimerization of compound $\mathbf{9}$ can also occur but without desulfurization, when 9d was treated with sodium nitrite/acetic acid mixture to give 11, which is in accordance with a previous result. ${ }^{14}$

Structure of compound $\mathbf{1 1}$ was derived from correct analytical data, its IR spectrum showed bands at 1640, 1340 and 3446 for C=N, -S-S-, OH. Its mass spectrum showed the parent ion peak at $\mathrm{m} / \mathrm{z} 726$ (40\%).

Reaction of 9a with acrylonitrile in boiling pyridine afforded the corresponding S-cyanoethylated product 12. Its mass spectrum showed ion peak at m/z 372 (M $\left.\left.\mathrm{CH}_{3}\right]^{+}\right)(74 \%)$.

Reaction of 9c with formaldehyde and morpholine (Mannich reaction) gave the Mannich base 13. Its IR spectrum showed bands at 1594 and $1240 \mathrm{~cm}^{-1}$ for $\mathrm{C}=\mathrm{N}$ and $\mathrm{C}=\mathrm{S}$, while its mass spectrum showed the parent ion peak at m/z 407 (50\%).

As a point of interest this investigation deals with the reaction of the pyrazolopyrimidine thione $\mathbf{9 c}$ and the pyrazoloimidazole thione $\mathbf{1}$ in boiling xylene 
9

in presence of copper bronze. The reaction proceeds through desulfurization and formation of compound 14. Its infrared spectrum was devoid of $v \mathrm{C}=\mathrm{S}$ and showed bands at 1616 and $3452 \mathrm{~cm}^{-1}$ for $\mathrm{C}=\mathrm{N}$ and $\mathrm{NH}$, while its ${ }^{1} \mathrm{H}-\mathrm{NMR}$ (DMSO- $\mathrm{d}_{6}$ ) spectrum exhibited signals at $\delta$ (ppm): 7.81-7.13 (13H, m, Ar-H), 2.13 (6H, s, 2 x $\left.\mathrm{CH}_{3}\right), 11.50(1 \mathrm{H}, \mathrm{s}, \mathrm{NH})$.
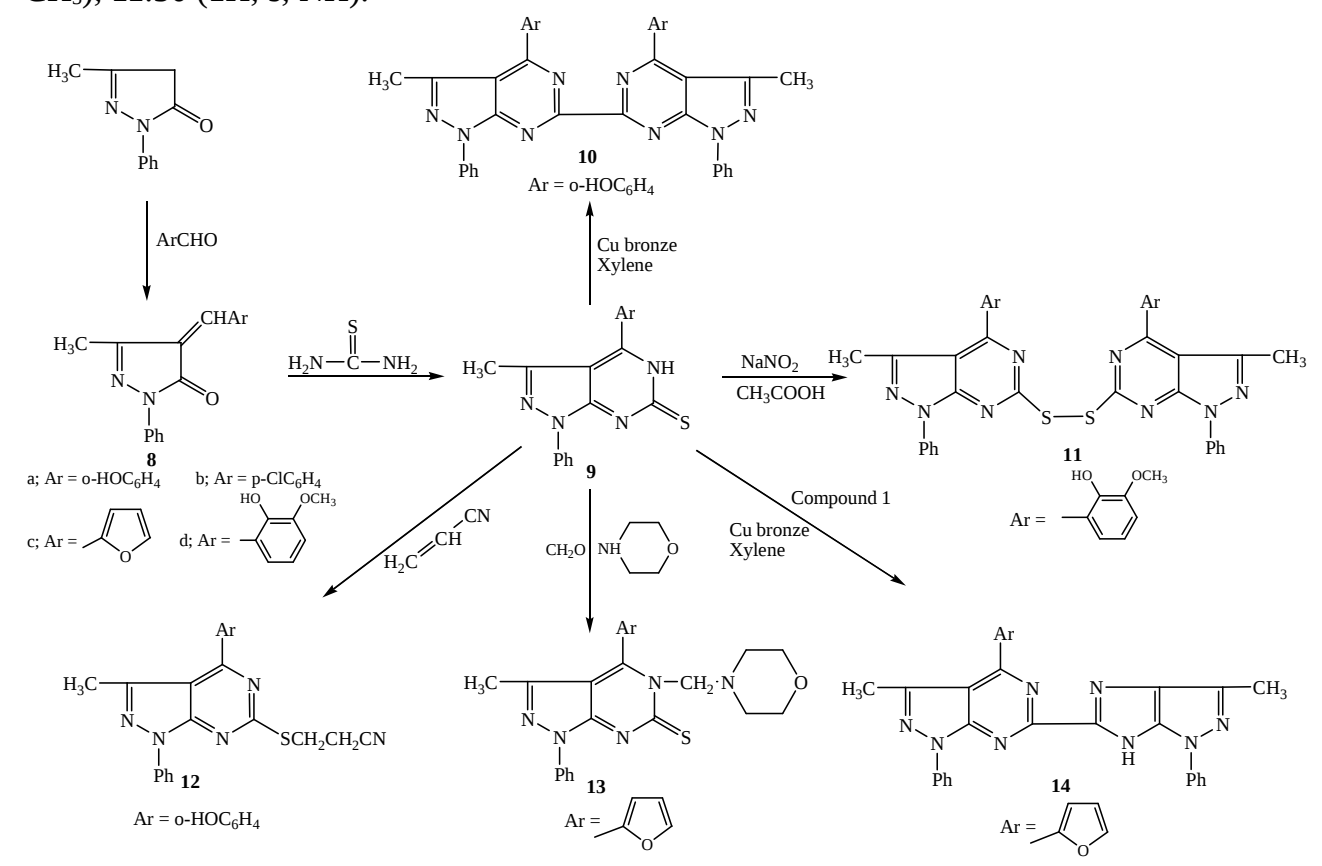

Scheme 1

\section{References}

1. IBRAHIM, A.M., SALEH, A.M. AND ZOHDI, H.F., Molecules 9, 109-116 (2004).

2. LIU, X., WANG, S. AND SONG, B., CHINESE J. Appl. Chem. 23(12), 1355-1358 (2006).

3. PARK, H., LEE, K., PARK, S., AHN, B., LEE, J., CHO, H. AND LEE, K., BIOORG. Med. Chem. Lett. 15(13), 3307-3312 (2005).

4. HALL, A., BIT, R.A., BROWN, S.H., CHOWDHURY, A., GILBIN, G.M.P., HURST, D.N., KILFORD, I.R., LEWELL, X., MAYLOR, A. AND SCOCCITI, T., BIOORG. Med. Chem. Lett. 18(5), 1592-1597 (2008). 
5. LUCA, L., Cur. Med. Chem. 13(1), 1-23 (2006).

6. IRADYAN, M.A., IRADYAN, N.S., STEPANYAN, G.M., ARSENYAN, F.G. AND GAZIBDZHANGAN, B.T., PHARM. Chem. J. 35(4), 183-185 (2001).

7. CHUNG, H., HONG, S., YOU, H., PARK, R. AND RYU, C., BIOORG. Med. Chem. 14(17), 5795-5801 (2006).

8. RASHAD, A.E., HEGAB, M.I., ABDEL-MEGEID, R.E., MICKY, J.A. AND ABDELMEGEID, F.M.E. BIOORG. Med. Chem. 16, 7102-7106 (2008).

9. SHAHEEN, F., BADASHAH, A., GIELEN, M., GIECK, C., JAMIL, M., AND DE VOS, D. J. Organomet. Chem. 693, 1117-1126 (2008).

10. SON, J., ZHAO, L., BASNET, A., THAPA, P., KARKI, R., NA, Y., JAHNG, Y., JEONG, T. CH., JEONG, B., LEE, C. AND LEE, E., Eur. J. Med. Chem. 43, 675-682 (2008).

11. ABD EL-GHAFFAR, N.F., KASSAB, R.R.S. AND SOLIMAN, F.M.A. Al-Azhar Bull. Sci. 11(1) 161-170 (2000).

12. ABD EL-GHAFFAR, N.F., DAWOOD, N.T. AND SOLIMAN, F.M.A. Al-Azhar Bull. Sci. 11(2) 147-154 (2000).

13. ABD EL-GHAFFAR, N.F., KADAH, M.S., RADWAN, A.M., ABD EL-AL, S.N. AND SALMAN, A.S. Al-Azhar Bull. Sci. (under press).

14. SAMMOUR, A., SELIM, M.I.B., NOUR EL-DEEN, M.M., ABD EL-HALIM, M., J. Egypt. Chem. 13(1), 7-24 (1970). 
1

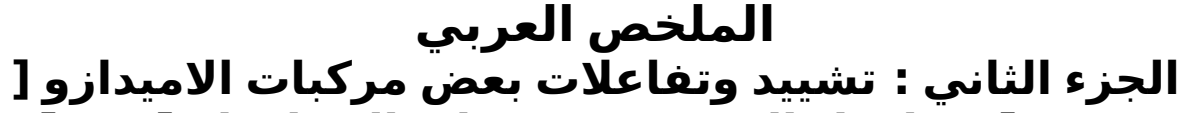

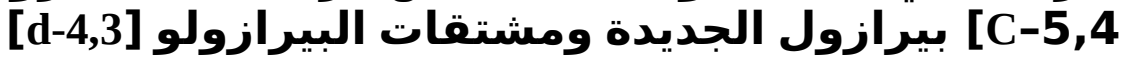

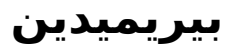

تفاعل 3-ميثيل -1 فنيل -4 ، 1 - 1 - داي هيدرواميدازو [C-5.4]

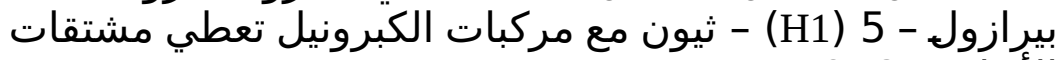
الأريلدين 2, 2, الرول ومع حمض الريسينوليك ، ومخلوط الفور ثالث كلوريد الفسفور / وخامس

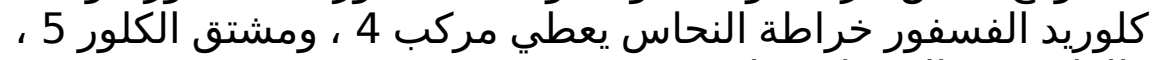

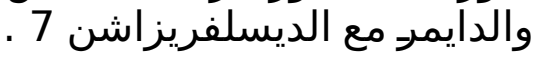
سلوك مشتق الكلور تجاه الهيدرازين والأمينات الأولية تم دراستها

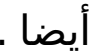

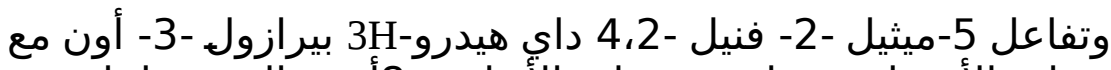

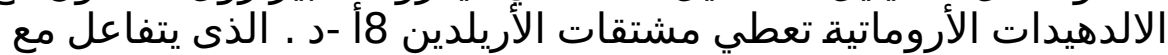
الثيويوريا ويعطي مشتق الأرمانية تلبيرازولو مشتوات بريميدين ثيون 9.

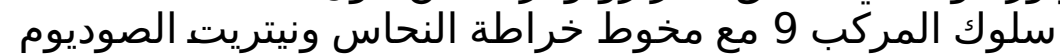

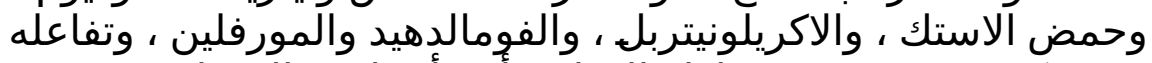

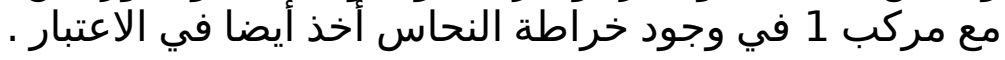

